\title{
LIGHT UNIFORMITY IMPROVEMENT INSIDE THE SPROUTING ENVIRONMENT AND PRODUCT EVALUATION
}

\author{
Khaled k. Hegab*
}

\begin{abstract}
Applying the condensed production technique in the spouting systems for recovering invested capital decreases light uniformity which minimizes quantity and quality of the product. The main objective of this research is to find suitable alternatives for improving light uniformity inside sprouting environment. Statistical approach was followed to design and analyze three types of practical trials. The first was applied to study light uniformity through variance analysis and drawing light contouring maps. The second was applied to design factorial trial containing twelve treatments. Four alternatives of production techniques: "condensed productions, condensed heart, open heart and amplified heart" on the horizontal levels. Three levels of light intensity: "low $\left(1800 \mathrm{~lm} / \mathrm{m}^{2}\right)$, medium $\left(36001 \mathrm{~m} / \mathrm{m}^{2}\right)$, and high $\left(54001 \mathrm{~m} / \mathrm{m}^{2}\right)$ " were tried on the vertical levels. The third was applied to study effects of using green fodder for feeding lactating Buffaloes on milk production. Geometric approach was applied to execute two types of technical tasks. The first was done to design and implement the four alternatives. The second was done to design and install automatic system control using PLC component for regulating light intensity and managing light duration inside sprouting environment. Physical and chemical measurements such as light intensity, fresh weight, dry weight, and percentage of crude protein, and crude fibers were done. The statistical analysis results revealed that applying the condensed heart technique under medium intensity of light $\left(36001 \mathrm{~m} / \mathrm{m}^{2}\right)$ through $12 / \mathrm{h}$.day (in exception of the first three days) saves one third of the used grains and upgrading the quality and quantity of the product. Using the sprouted fodder in lactating buffaloes' rations led to significant increase in quantity and quality of milk.
\end{abstract}

Keywords: light uniformity- light intensity- sprouting productionproduction technique-automatic control-PLC component.

*Agric. Eng. Dept., Fac. of Agric., Cairo U., Egypt. 


\section{INTRODUCTION}

1.1 The research problem and objective: Although, the sprouted green fodder is produced under complete control conditions of light, temperature, humidity, irrigation, and fertigation, variation in the sprouted barley fresh weight, color, and dry matter is remarked. Due to limitation of vertical distance between rows, the remarked variation of light intensity is high. This variation is clearly remarked between the located production close to the light sources and located away from the light sources, Hegab 2017a, and Hegab 2017b. As a result, absence of light uniformity inside the sprouting environment is considered a critical problem. The main objective of this research is to determine the best alternative for spatial distribution of the production to improve light intensity which maximizes the quantity and quality of the proposed production.

1.2 Artificial light sources for plants: Artificial light is considered common techniques to increase greenhouse production of crops to meet the world's growing demand of food, Mahdavian and Wattanapongsakorn 2017. LED light has positive effects on photosynthetic indices, growth, yield and nutritional value in green vegetables and tomato, cucumber, sweet pepper transplants, Oile and Virsile 2013. LED is used in module for cultivation for tomatoes transplants for increasing its quality, Brazaityte et al. 2010. High intensity blue LEDs $(238 \mu \mathrm{mol} \mathrm{m}-2 \mathrm{~s}-1)$ increase plant (lettuce leaves) growth rate through controlling the integrity of chloroplast proteins that maximize photosynthetic performance in the natural environment, Muneer et al. 2014. (LEDs) are considered one of the world's most important lighting sources and their integration in microalgal production systems (photobioreactors) needs to be considered, Schulze et al. 2014. Beside the natural light "sunlight", using blue LEDs ranging from 83upto $230 \mu$ molm-2 s -1 as additional lighting increases the growth and internal quality such as chlorophyll, carotenoids and polyphenol content in Polygonum odoratum plants, Grbic et al. 2014. Light intensity significantly affected stomata density of in petunia (Petuniahybrida Vilm.) plants under a semi-closed system. This affect could partially explain an increasing of daily stomata conductance (gs), stomata aperture 
movement and stomata density in response to increasing light intensity, Sakhonwasee et al. 2017.

Light-Emitting Diode fixtures LED cost is five to ten times more than High Pressure Sodium fixtures HPS. Due to high capital costs, the five year electric consumption plus fixture cost per mole of photons is thus 2.3 times higher for LED, Nelson and Bugbee (2014). LED fixtures are a more energy-efficient and emit less heat than HPS fixtures. Therefore, LED fixtures can be brought much closer to plant tissues. To optimize the plant growth, the seedlings are placed directly below the light source, Carney et al. 2016. The controlling systems are implementing in agriculture to execute complex process "such as environmental control, and irrigation management" that need consideration of several significant factors, I.arif and Abbas (2015). The blue LEDs lamps $(450 \mathrm{~nm})$ are equally, or even more efficient than the red lamps, Ahlman et al. 2017.

1.3 Light uniformity and control system: Light uniformity indicators, coefficient of variation (CV) and uniformity gradient (UG), are considered important indicators for measuring the quality of lighting system, Houser et al. 2011. Light source location inside the plants growth chambers improve the lighting uniformity within the space, Delepoulle et al. 2009. Executing a balance between nutrients $\left(\mathrm{NH}_{4}+\right.$, $\mathrm{K}+, \mathrm{Mg} 2+, \mathrm{Ca} 2+, \mathrm{NO}_{3}-, \mathrm{H}_{2} \mathrm{PO}_{4}^{-}, \mathrm{SO}_{4} 2^{-}$) and light (intensity, uniformity and quality) optimizes the photosynthetic rate, transpiration rate, antioxidant capacity and biomass yield, Dong et al. 2014. Light intensity is considered one of the environmental factors affecting the prediction of the growth of $C$. vulgaris, Aminia et al. 2018. Specific LED wavelengths, have great effects on stomatal responses, leaf area, chlorophyll content and flowers of carnation inside a greenhouse environment, Senola et al. 2016. Artificial lighting control systems in commercial scale greenhouses have a large potential for increased crop yields, energy savings and timing in greenhouse production, Carstensen et al. 2017. Upgrading the efficiency and reproducibility of light control methods used for plant production is improving light intensity distribution on a plant canopy surface, Miyoshi et al. 2016. Developing a low-cost and open-source tool for improving and promoting cultivation 
of plants using LEDs is considered critical issue for cultivation process, Wishkerman and Wishkerman 2017. Beside the traditional system, smart illumination systems (ILSys) could be designed and fabricated to study the growth process of green plants. The systems idea is controlling LED lamps that can be turned on to emit continuous or pulsed light, Gonzalez et al. 2013.

1.4 Rice straw: Globally, the great amounts of rice straw "as by product of the rice production" are mainly used as a direct source of feed introduced to ruminant animals, Sarnklong et al. 2010. Also, rice straw material as a raw material, is used for producing paper, fuel, bioenergy, fertilizer, biogas, building materials and compost, Kaur et al. 2017, Saidab et al. 2013, Ishii and Furuichi 2014, Riya eat al. 2018, Yeab et al. 2013 and Zhou et al. 2015.

\section{MATERIALS AND METHODS}

2.1. Sprouting and growth chamber design: The sprouting and growth chamber was locally designed and fabricated with dimensions of 4, 6, and $3 \mathrm{~m}$ for wide, length, and high respectively, Fig. (1). Wiring and lighting systems were locally designed and fabricated, Figs. (2) and (3). Blue LED tube lamps with specifications of $120 \mathrm{~cm}, 25 \mathrm{~mm}, 18 \mathrm{~W} / 220 \mathrm{~V}$, and $1800 \mathrm{~lm}$ for length, diameter, power, and luminous flux were used respectively. This chamber contains three stands each of them was divided into nine rows, Fig. (4). Each row is designed to receive 16 sprouting trays with dimensions of 30,90 and $3 \mathrm{~cm}$ wide, long, and high respectively. The chamber's door forced the designer to leave entrance area which reduces the trays numbers in the first and the second stands. As a result, the total production capacity of the chamber is 432 tray per cycle.

2.2. Lighting system design: Lighting system was designed for controlling on lighting intensity and lighting duration inside the chamber, Fig. (5). Programmable logic controller (PLC) was used as main component of a control panel for fixing light intensity and lighting duration inside the chamber. This panel contains one source of Power Supply 220V AC, one Switch-Mode Power Supply (SMPS), three transformers 220/12V AC, one PLC 8 I/O, two Relays 8PIN/12V DC and three switch contactors. 


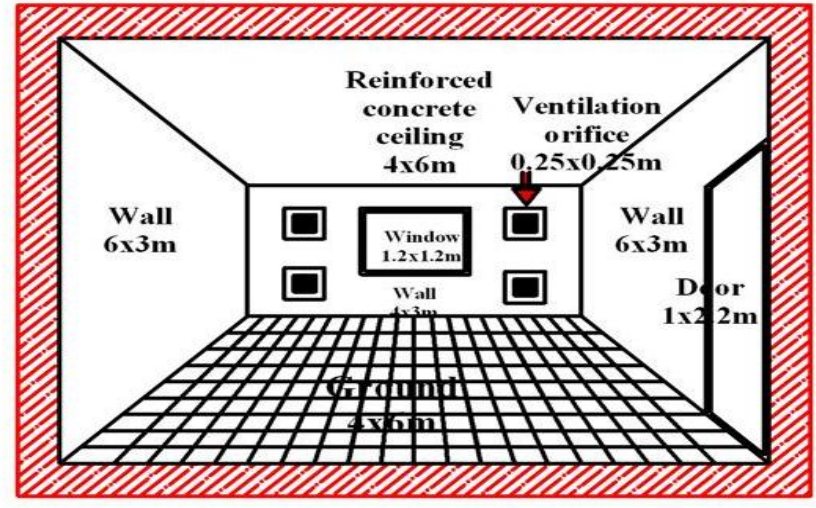

Fig. (1) : Main dimensions of the chamber.

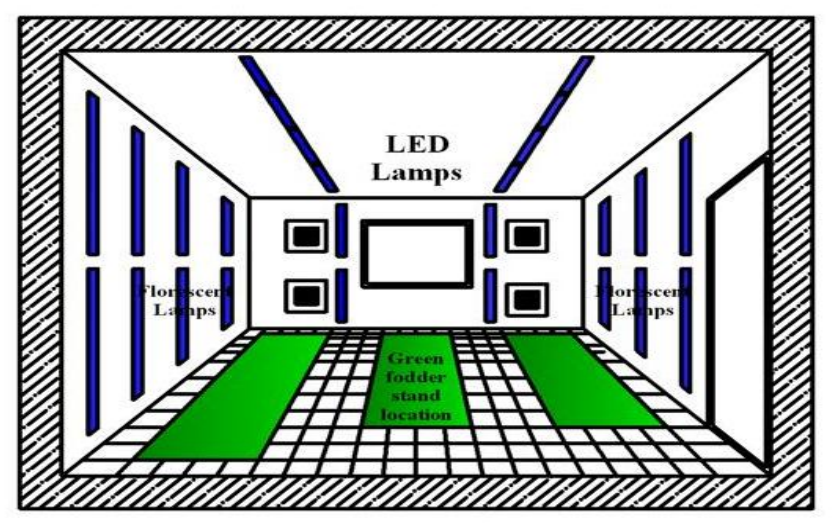

Fig. (3) : LED light distribution .

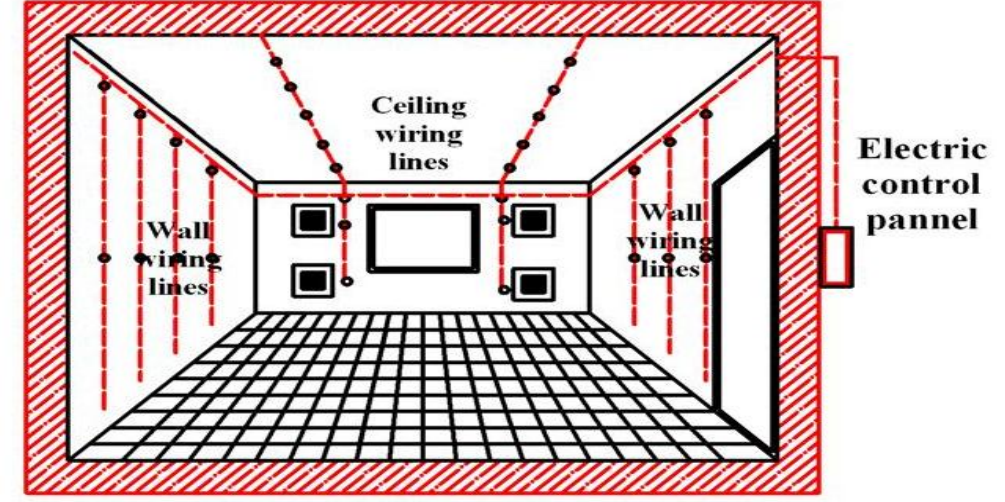

Fig. (2) : Planning of wiring system .

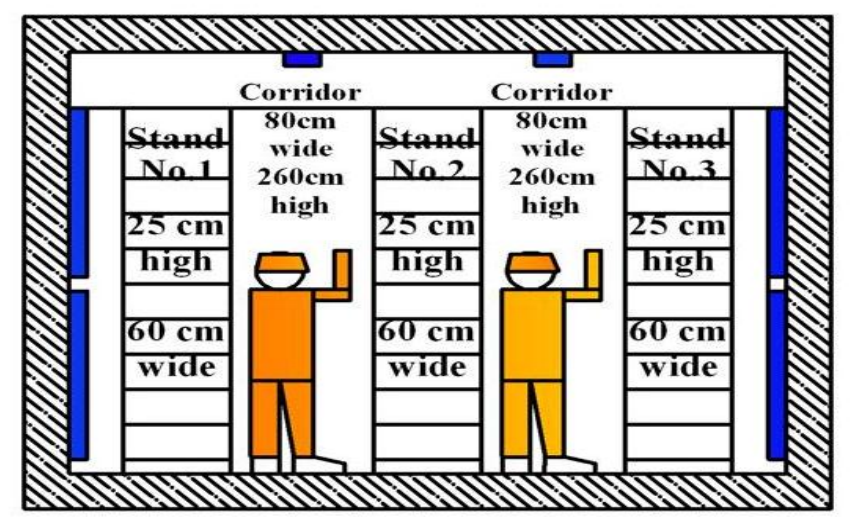

Fig. (4) : Dimensions of the utilized stands. 


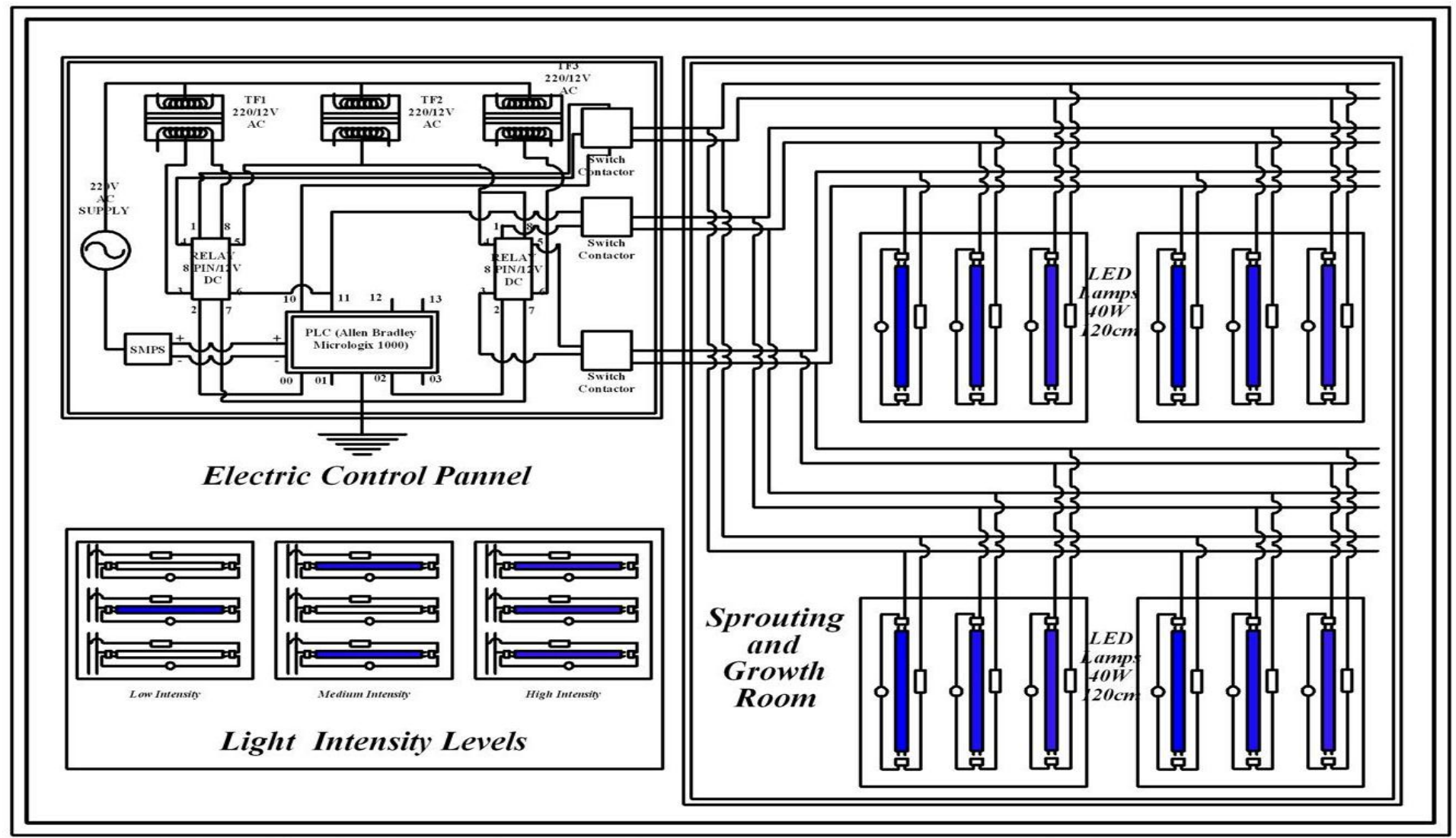

Fig. (5): Design of sprouting and growth room lighting system. 
Three groups of blue LED tube lamps were connected with the power source through specific wiring system. This system was designed for lighting the chamber on three levels of intensity to meet the needs of the lighting trial. Lighting one, two and three groups gives low, medium, and high intensity of light inside the chamber.

2.3. Lighting trial design: To study light uniformity within the chamber and its effect on the proposed production, factorial experiment in complete randomization was statistically designed, table (1). The trial design consists of three levels of light intensity and four levels of production density. Number of florescent lamps per square meter of chamber ground was used as a main criterion for light intensity. Blue Tube LED Lamps with $(1800 \mathrm{~lm})$ was used for lighting the chamber. Twenty four lighting units, each of them containing three lamps, were installed inside the chamber. The three levels of light intensity were 1.0

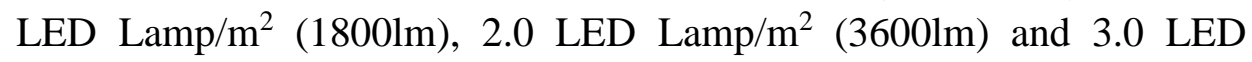
Lamp $/ \mathrm{m}^{2}(54001 \mathrm{~m})$ respectively. Trays number per cubic meter of the growth room space was used as a main criterion for production density. The chamber contains three stands each of them was divided into nine rows with height of $25 \mathrm{~cm}$. The four levels of production density were produced from four alternatives of spatial distribution of the trays within the chamber. The first alternative was called Condensed Production and constructed from using all rows of the three stands giving $5.58 \mathrm{Tray} / \mathrm{m}^{3}$, Fig. (6). The second was called Condensed Heart constructed from using row after rows of the outer stands and all rows of the heart giving 3.72 Tray $/ \mathrm{m}^{3}$ Fig. (7). The third was called Vacated Heart constructed from using all rows of the other stands giving $3.72 \mathrm{Tray} / \mathrm{m}^{3}$ Fig. (8). The fourth was called Amplified Production constructed from using row after row of the all stands, giving $2.79 \mathrm{Tray} / \mathrm{m}^{3}$, Fig. (9).

2.4. Lighting trial measurements and analysis: The chamber space was divided into three cross section (with dimension of $4 \mathrm{~m}$ wide and $3 \mathrm{~m}$ high) each section was divided into square network of $0.5 \times 0.5$ meter giving 63 cross points. Lux meter was used to measure light intensity $\left(\mathrm{lm} / \mathrm{m}^{2}\right)$ at each cross point for the 12 treatments of the lighting. The measurements were statistically analyzed and presented in contouring maps by "Surfer 13" computer program. The program was used for 
dealing with the whole section and zooming on the heart zone section for analyzing the inner data and drawing more details of the contouring maps.

Table (1): Statistical trial design for studying light uniformity effect.

\begin{tabular}{|c|c|c|c|c|c|}
\hline & \multicolumn{4}{|c|}{$\begin{array}{c}\text { Production Density } \\
\left(\text { Tray } / \mathrm{m}^{3} \text { of the growth room space }\right)\end{array}$} \\
\hline & & $\begin{array}{c}\text { Condensed } \\
\text { Production } \\
5.58 \\
\text { Tray } / \mathrm{m}^{3}\end{array}$ & $\begin{array}{c}\text { Condensed } \\
\text { Heart } \\
3.72 \\
\text { Tray } / \mathrm{m}^{3}\end{array}$ & $\begin{array}{c}\text { Vacated } \\
\text { Heart } \\
3.72 \\
\text { Tray } / \mathrm{m}^{3}\end{array}$ & $\begin{array}{c}\text { Amplified } \\
\text { Production } \\
2.79 \\
\text { Tray } / \mathrm{m}^{3}\end{array}$ \\
\hline \multirow{3}{*}{$\begin{array}{c}\text { Light } \\
\text { Intensity } \\
\text { Illuminance } \\
\left(1 \mathrm{~m} / \mathrm{m}^{2}\right)\end{array}$} & $\begin{array}{c}\text { Low } \\
\text { Intensity } \\
1800 \\
\left(1 \mathrm{~m} / \mathrm{m}^{2}\right) \\
\end{array}$ & $\mathbf{T}_{1}$ & $\mathbf{T}_{2}$ & $\mathbf{T}_{\mathbf{3}}$ & $\mathbf{T}_{4}$ \\
\hline & $\begin{array}{c}\text { Medium } \\
\text { Intensity } \\
3600 \\
\left(1 \mathrm{~m} / \mathrm{m}^{2}\right)\end{array}$ & $\mathbf{T}_{5}$ & $\mathbf{T}_{6}$ & $\mathbf{T}_{7}$ & $\mathbf{T}_{8}$ \\
\hline & $\begin{array}{c}\text { High } \\
\text { Intensity } \\
5400 \\
\left(1 \mathrm{~m} / \mathrm{m}^{2}\right)\end{array}$ & $\mathbf{T}_{9}$ & $\mathbf{T}_{10}$ & $\mathbf{T}_{11}$ & $\mathbf{T}_{12}$ \\
\hline
\end{tabular}

2.5. Sprouting trial design, measurements and analysis: Barley grains were sprouted on rice straw media for green fodder production. The grains were washed, soaked in water (5-6h) and composted for complete 24 hours before cultivation. Systematically, $500 \mathrm{~g}$ of dry grains and $250 \mathrm{~g}$ of rice straw with physical dimensions of less than $5 \mathrm{~cm}$ in average were applied in each tray. The lighting program was designed to be off through the first three days of the life cycle (9days). Root layer thickness RLT "cm", vegetation high $\mathrm{VH}(\mathrm{cm})$, fresh weight of green fodder (FW) "kg/tray", Fresh weigh $\mathrm{kg}$ and total dry matter weight $\mathrm{kg} / \mathrm{cycle}$ and percentage of "dry matter DMP, Ash, crude protein Cp, crude fiber percentage $\mathrm{Cf}$ and ether extract $\mathrm{EE}$, nitrogen free ether NFE" were studied and analyzed.

2.6. Lactating buffaloes trial: Nine lactating Egyptian buffaloes were divided into three groups. Each group of buffaloes was fed on one of the three rations with different contents of forage either Darawa, Darawa plus green barley or green barley in $3 \times 3$ Latin Square's design. Lactating Buffaloes in the trial groups were fed forage and concentrate feed mixture $(\mathrm{CFM})$ by $50 \%$ concentrate: $50 \%$ roughage. 


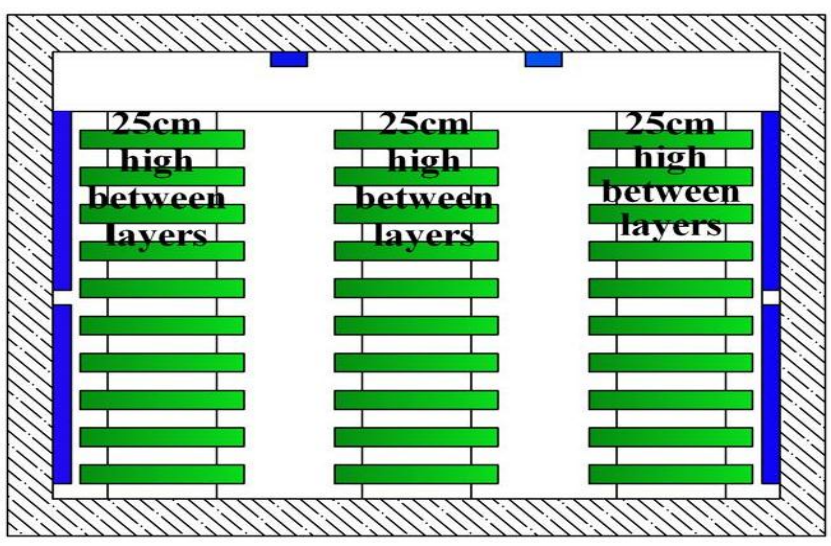

Fig. (6) :Condesed production.

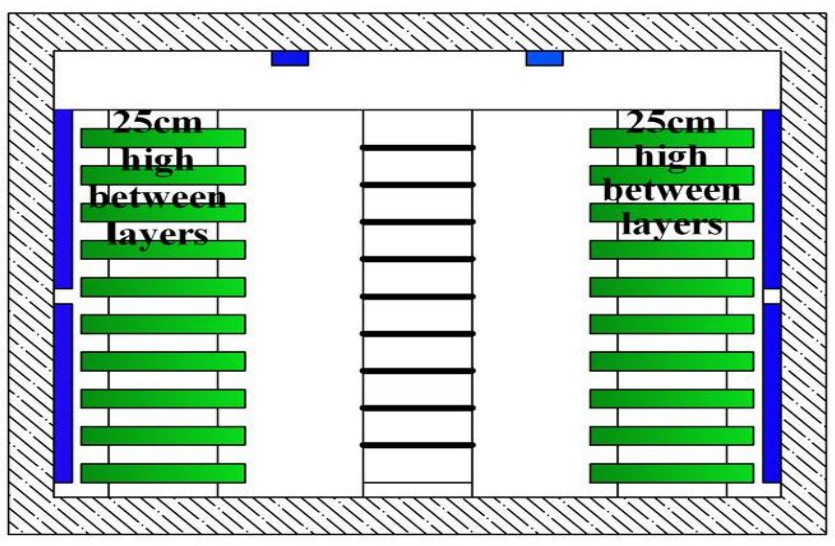

Fig. (8) : Vacated heart.

Misr J. Ag. Eng., April 2018

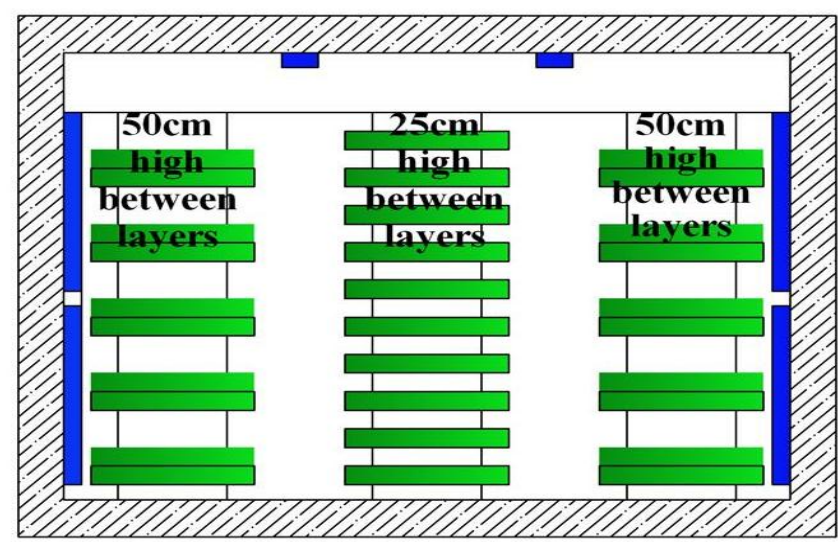

Fig. (7) : Condensed heart.

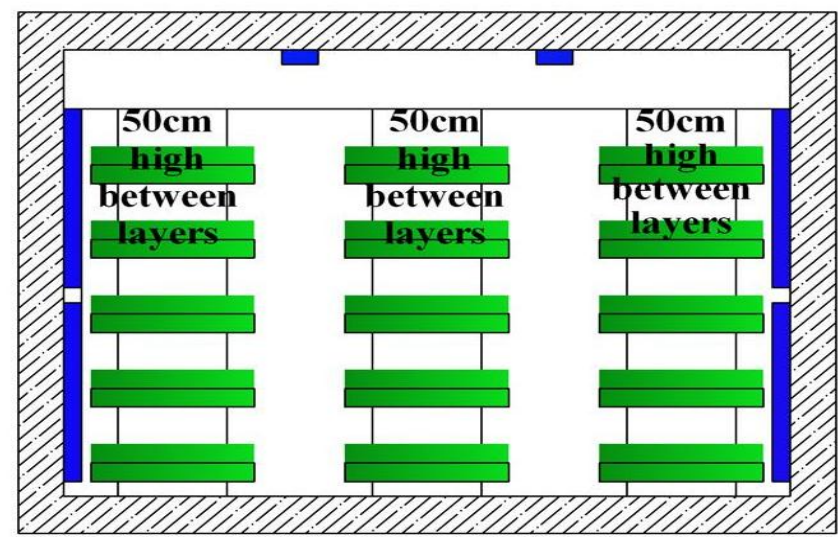

Fig. (9) : Amplified production.

-751 - 


\section{RESULTS AND DISCUSSIONS}

3.1. Production densities under low intensity light: Fig. (10a) shows light intensity contouring map for the chamber full section $(4 \times 3 \mathrm{~m})$ through condensed production at low intensity of light $\left(43201 \mathrm{~m} / \mathrm{m}^{2}\right)$. The majority of contouring lines are located within $50 \mathrm{~cm}$ of the light sources. The values of these contour lines are decreased from 5500 at the light sources to $500\left(\mathrm{~lm} / \mathrm{m}^{2}\right)$ at $50 \mathrm{~cm}$ distance from the light sources. According to the light intensity definition, it was expected that the light intensity value at $50 \mathrm{~cm}$ distance from the light source is $\left(1800 \mathrm{~m} / \mathrm{m}^{2}\right)$. The remarked decrease could be referred to two main reasons. The first is the shadow effect of the sprouting plants.

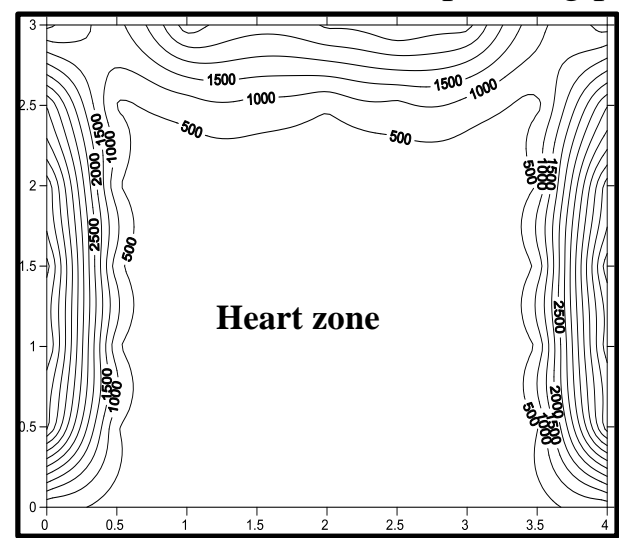

Fig. (10a): Light contouring map for condensed produc tion $\left(T_{1}\right)$.

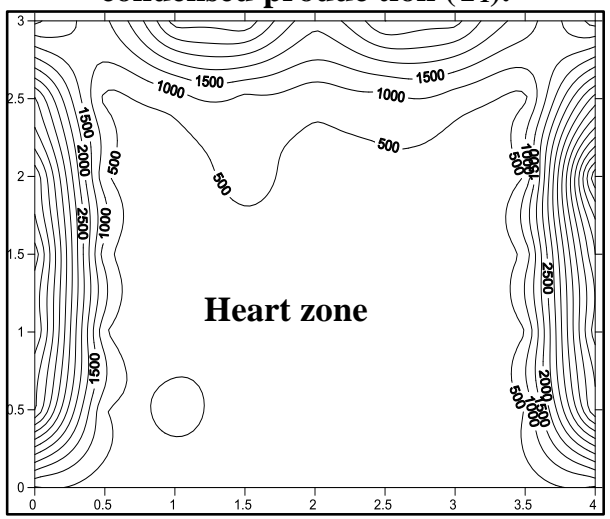

Fig. (10c): Light contourin $g$ map for vacated heart $\left(\mathrm{T}_{3}\right)$.

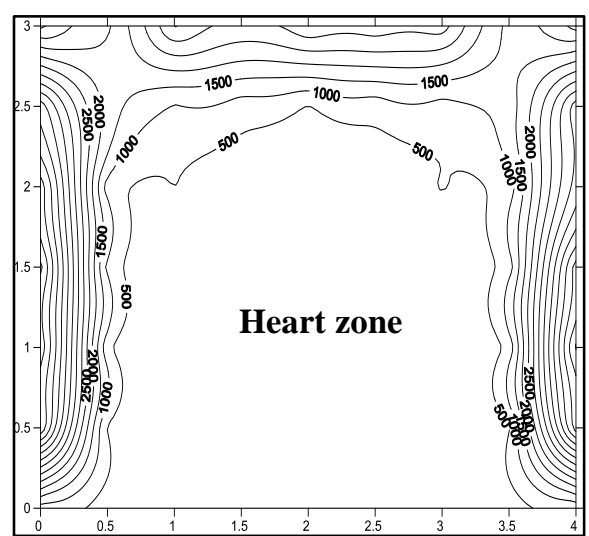

Fig. (10b): Light contouring map for condensed heart $\left(T_{2}\right)$.

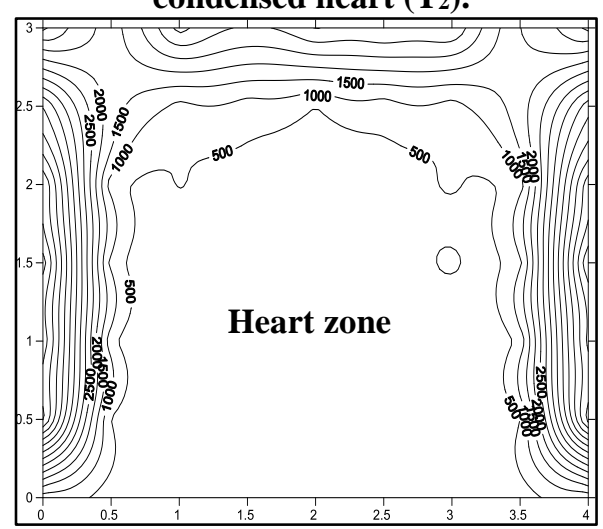

Fig. $\left(1_{d}\right)$ : Light contouring map for amplified heart $\left(\mathbf{T}_{4}\right)$.

Fig. (10): Light contouring map of the chamber full section under low intensity light. 
The second is the reverse relation between light intensity and distance from the light source " $E_{2}=\left(d_{1} / d_{2}\right)^{2} E_{1}$ ". Fig. (11a) shows light intensity contouring map of the heart zone $(3 \times 2.5 \mathrm{~m})$ of the sprouting and growth chamber through condensed production under low light intensity. The values of these contour lines decrease from $500\left(1 \mathrm{~m} / \mathrm{m}^{2}\right)$ at $50 \mathrm{~cm}$ distance from the light sources to $50\left(1 \mathrm{~m} / \mathrm{m}^{2}\right)$ at the center of the chamber at the ground surface. This decrease could be referred to the same reasons mentioned above. These results agree with the principles of light physics, such as Young et al. 2008 and Zumtobel 2017.

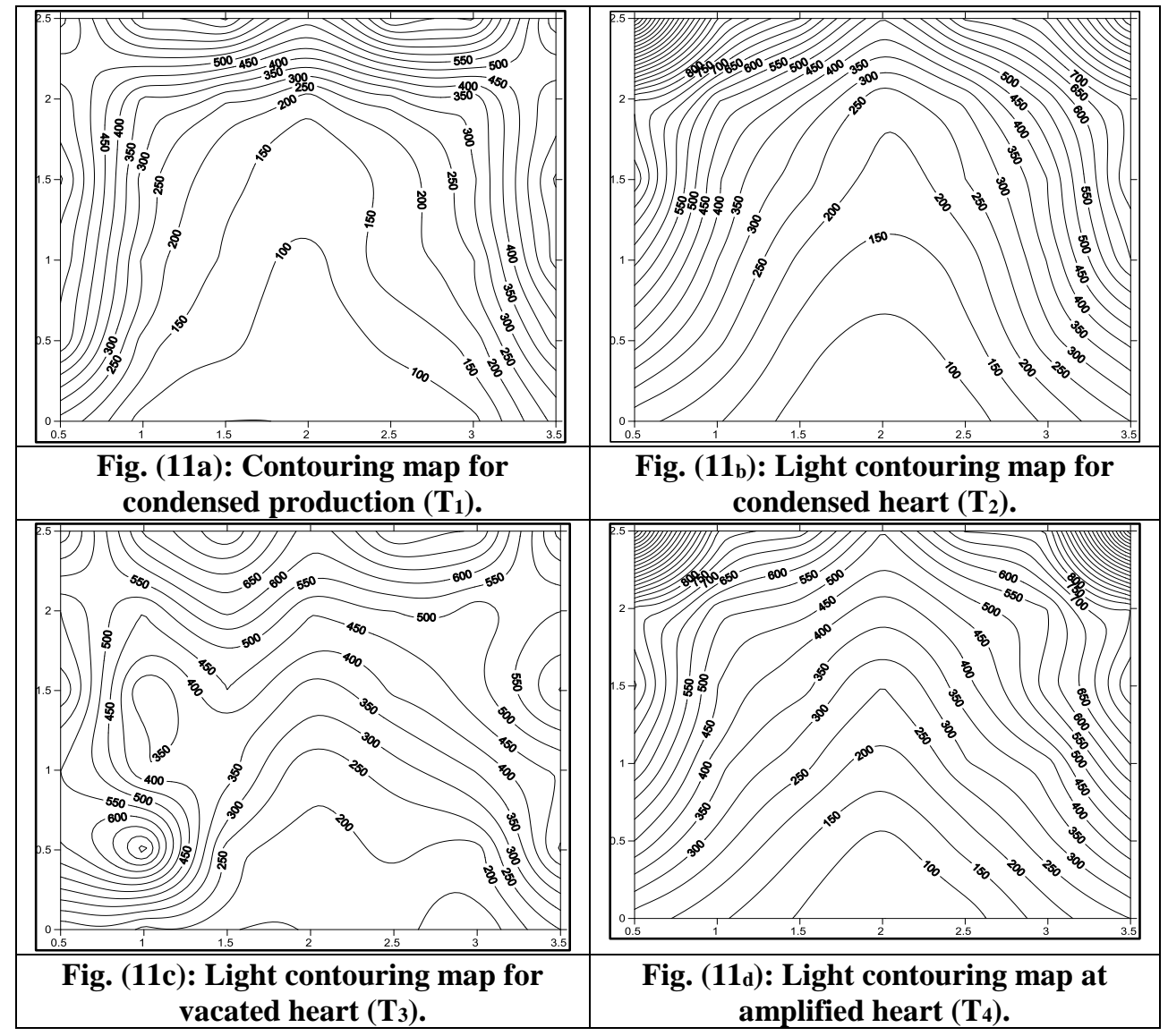

Fig. (11): Light contouring map of the chamber heart zone under low intensity light.

Table (2) summarizes the statistical analysis results of the collected light intensity data. This table was divided into two main portions. The left side of this table deals with the full section data analysis, and the right side 
deals with the heart zone data analysis. The left side of the first raw shows the values of mean, variance, standard deviation and standard error of the full section data analysis through condensed production under low light intensity. The value of the mean " 1424 " is very small comparing with its value "5500" at the light sources. As a result, values of the variance, standard deviation and standard error are very high. The right side of this row shows the values of mean, variance, standard deviation and standard error of the heart zone data analysis. The value of the mean "330" is small comparing with its value " 5500 " at the light sources. As a result, values of the variance, standard deviation and standard error are very high. These results agree with the principles of statics, such as Landau and Everitt 2004, Toutenburg and Shalabh 2009, and Aminia et al. 2017.

Table (3) shows the quality and quantity specifications of the sprouted and grown barley green fodder on the rice straw media. The first raw of this table shows the values of the product quality and quantity specifications through condensed production under low light intensity. Values of the manifested criteria are smaller than their values in the remainder rows in the first group (under low intensity). The remarked minimization in these criteria is referred to the small value of light intensity mean and the high value of variation of light intensity through the full cross section of the chamber. These results agree with Mahdavian and Wattanapongsakorn 2017 and Oile and Virsile 2013.

Figs. (10b) and (11b) show contouring maps for full section and heart zone through condensed heart under low intensity. Due to duplication of the vertical distance between rows in the outer stands, improvement of contouring maps were remarked. As a result, improvement of statistical results and the product criteria in the second row in tables (2) and (3). The improvement of the product agree with Grbic et al. 2014, Sakhonwasee et al. 2017 and Carney et al. 2016.

Figs. (10c) and (11c) show contouring maps for full section and heart zone through open heart under low intensity. Because of the open heart improvement of contouring maps were remarked. Improvement of statistical results are shown in the third raw of table (2). 
Table (2): Light distribution statistical analysis.

\begin{tabular}{|c|c|c|c|c|c|c|c|c|}
\hline \multirow[b]{2}{*}{$\begin{array}{c}\text { Treatment } \\
\text { No. }\end{array}$} & \multicolumn{4}{|c|}{ Full Section } & \multicolumn{4}{|c|}{ Heart Zone } \\
\hline & $\begin{array}{l}\text { Mean } \\
\text { (Lux), } \\
\text { lm/m² }\end{array}$ & Variance & S.D. & S.E. & $\begin{array}{l}\text { Mean } \\
\text { (Lux), } \\
\text { lm/m² }\end{array}$ & Variance & S.D. & S.E. \\
\hline $\mathbf{T}_{1}$ & $1424.11^{\mathrm{dl}}$ & $510609.3^{\mathrm{a}}$ & 720.3 & 91.18 & $330.06 \mathrm{~d}$ & $50031^{a}$ & 225.47 & 28.54 \\
\hline $\mathbf{T}_{2}$ & $1570.56^{\mathrm{bl}}$ & $462470.9^{\mathrm{cl}}$ & 685.5 & 86.80 & $438.97^{b}$ & $41341^{\mathrm{c}}$ & 204.96 & 25.95 \\
\hline $\mathbf{T}_{3}$ & $1556.40^{\mathrm{cl}}$ & $467539.9^{\mathrm{bl}}$ & 689.3 & 87.25 & $425.00 \mathrm{c}$ & $43699^{b}$ & 210.73 & 26.68 \\
\hline $\mathbf{T}_{4}$ & $1668.34^{\mathrm{al}}$ & $432994.5^{\mathrm{dl}}$ & 663.3 & 83.96 & $606.12^{\mathrm{a}}$ & $35545^{\mathrm{d}}$ & 196.05 & 24.05 \\
\hline $\mathbf{T 5}$ & $2431.90^{\mathrm{dm}}$ & $1425195^{\mathrm{am}}$ & 1203.25 & 152.35 & $675.55^{\mathrm{d}}$ & 190270 & 439.70 & 55.65 \\
\hline $\mathbf{T}_{6}$ & $2819.39^{\mathrm{bm}}$ & $1229124^{\mathrm{cm}}$ & 1117.56 & 141.46 & $963.07^{\mathrm{b}}$ & 162258 & 406.05 & 51.40 \\
\hline $\mathbf{T}_{7}$ & $2596.85^{\mathrm{cm}}$ & $1331699^{\mathrm{bm}}$ & 1163.55 & 147.25 & $853.31^{\mathrm{c}}$ & 188386 & 437.50 & 55.40 \\
\hline $\mathbf{T}_{8}$ & $2943.30^{\mathrm{am}}$ & $1126829^{\mathrm{dm}}$ & 1070.06 & 135.45 & $1000.07^{\mathrm{a}}$ & 149585 & 389.86 & 49.35 \\
\hline T9 & $3299.36^{\mathrm{dh}}$ & $2471961^{\mathrm{ah}}$ & 1584.33 & 200.62 & $833.45 \mathrm{~d}$ & 443587 & 671.35 & 84.95 \\
\hline $\mathbf{T}_{10}$ & $3528.03^{\text {bh }}$ & $2318015^{\mathrm{ch}}$ & 1534.54 & 194.25 & $1239.71^{\mathrm{b}}$ & 350401 & 596.71 & 75.51 \\
\hline $\mathbf{T}_{11}$ & $3485.92^{\text {ch }}$ & $2331842^{\text {bh }}$ & 1538.30 & 194.90 & $910.00^{c}$ & 392920 & 631.81 & 79.98 \\
\hline $\mathbf{T}_{12}$ & $3638.94^{\text {ah }}$ & $2289241^{\text {dh }}$ & 1525.17 & 193.05 & $1368.00^{\mathrm{a}}$ & 313920 & 564.69 & 71.51 \\
\hline
\end{tabular}

where: S.D. is standard deviation and S.E. is standard error. 
Table 3: Effects of light on the sprouted hydroponics barley on rice straw.

\begin{tabular}{|c|c|c|c|c|c|c|c|c|c|c|}
\hline \multirow{2}{*}{ 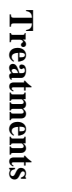 } & \multicolumn{10}{|c|}{ Variables means and ranks } \\
\hline & RLT & VGH & $\begin{array}{c}\text { DM } \\
\%\end{array}$ & $\begin{array}{c}\text { Ash } \\
\%\end{array}$ & $\begin{array}{c}\text { Cp } \\
\%\end{array}$ & $\begin{array}{l}\text { Cf } \\
\%\end{array}$ & $\begin{array}{c}\mathbf{E E} \\
\%\end{array}$ & $\begin{array}{c}\text { NFE } \\
\%\end{array}$ & $\begin{array}{c}\text { FW } \\
\text { kg }\end{array}$ & $\begin{array}{c}\text { TDM } \\
\text { kg }\end{array}$ \\
\hline $\mathbf{T}_{1}$ & 1.5 & 16.3 & 10.5 & 3.5 & 12.1 & 13.0 & 3.30 & 57.60 & 5.50 & 233.89 \\
\hline $\mathbf{T}_{2}$ & $1.4^{\mathrm{b}}$ & $17.0^{b}$ & $13.5^{\mathrm{b}}$ & $4.3^{b}$ & $15.7^{\mathrm{a}}$ & $14.7^{b}$ & $2,90^{b}$ & $48.90^{a}$ & $6.50^{b}$ & $236.90^{b}$ \\
\hline $\mathbf{T}_{3}$ & 1.6 & 16.0 & 12.5 & 4.0 & 14.5 & 14.2 & 3.06 & 51.47 & 6.50 & 219.38 \\
\hline $\mathbf{T}_{4}$ & 1.65 & 14.5 & 13.0 & 4.5 & 14.7 & 15.0 & 2.75 & 50.05 & 5.50 & 160.87 \\
\hline $\mathbf{T}_{5}$ & 1.6 & 17.0 & 11.5 & 4.0 & 15.1 & 13.8 & 3.15 & 52.45 & 6.0 & 279.54 \\
\hline $\mathbf{T}_{6}$ & $1.5^{\mathrm{b}}$ & $18.3^{\text {ab }}$ & $14.7^{\mathrm{a}}$ & $4.5^{b}$ & $16.8^{\mathrm{a}}$ & $15.7^{\mathrm{a}}$ & $3.25^{\mathrm{a}}$ & $49.25^{a}$ & $7.1^{\mathrm{a}}$ & $281.80^{a}$ \\
\hline $\mathbf{T}_{7}$ & 1.7 & 16.7 & 13.2 & 4.7 & 16.0 & 16.1 & 3.13 & 46.87 & 6.9 & 245.92 \\
\hline $\mathbf{T}_{8}$ & 1.7 & 17.5 & 13.5 & 4.6 & 16.3 & 16.0 & 3.30 & 46.30 & 6.7 & 203.50 \\
\hline $\mathbf{T}_{9}$ & 2.2 & 18.3 & 12.1 & 4.0 & 15.4 & 15.9 & 3.30 & 49.30 & 6.10 & 298.90 \\
\hline $\mathbf{T}_{10}$ & $2.0^{\mathrm{a}}$ & $19.0^{a}$ & $14.8^{a}$ & $5.0^{\mathrm{a}}$ & $16.7^{\mathrm{a}}$ & $16.2^{\mathrm{a}}$ & $2.25^{b}$ & $45.10^{b}$ & $7.50^{\mathrm{a}}$ & $299.70^{a}$ \\
\hline $\mathbf{T}_{11}$ & 2.3 & 18.5 & 14.0 & 5.2 & 16.1 & 16.3 & 3.45 & 44.95 & 7.25 & 274.05 \\
\hline $\mathbf{T}_{12}$ & 2.3 & 18.0 & 14.5 & 5.5 & 16.5 & 16.5 & 3.59 & 43.41 & 7.20 & 234.90 \\
\hline
\end{tabular}

Due to limitation of the vertical distance between rows in the outer stands, the impact of the open heart on the product is limited. As a results, improvement of the product criteria in the third row in table (3). This result agrees with Brazaityte et al. 2010, Muneer et al. 2014 and Aminia et al. 2018

Figs. (10d) and (11d) show contouring maps for full section and heart zone through amplified production under low intensity. Due to duplication of the vertical distance between rows, improvements of contouring maps were remarked. As a result, improvement of statistical results and the product criteria are in the fourth row in tables (2) and (3). This result agrees with Dong et al. 2014 and Aminia et al. 2018.

3.2. Production densities under medium intensity of light: Figs. (12a, b, c and d) and (13a, b, c and d) show contouring maps of condensed production, condensed heart, open heart and amplified production under medium intensity light. Rows No. 5 to 8 in tables (2) and (3) show light intensity variances, and the product criteria of condensed production, 
condensed heart, open heart and amplified production under medium intensity of light. Due to the simulation in exception of the intensity light $\left(86401 \mathrm{~m} / \mathrm{m}^{2}\right)$, these results take the same trend mentioned above but in greater values. This result agrees with Senola et al. 2016 and Wishkerman and Wishkerman 2017

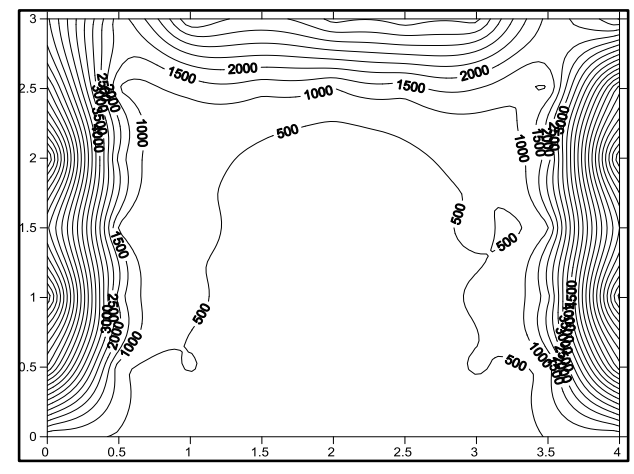

Fig. (12a): Light contouring map at condensed production $\left(\mathbf{T}_{5}\right)$.

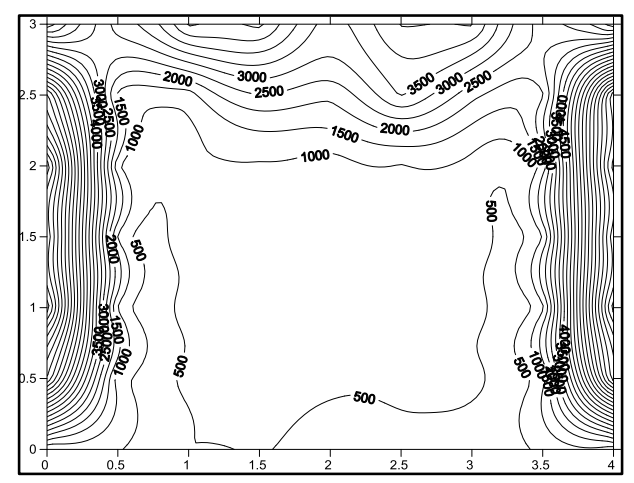

Fig. (12c): Light contouring map at vacated heart $\left(\mathbf{T}_{7}\right)$.

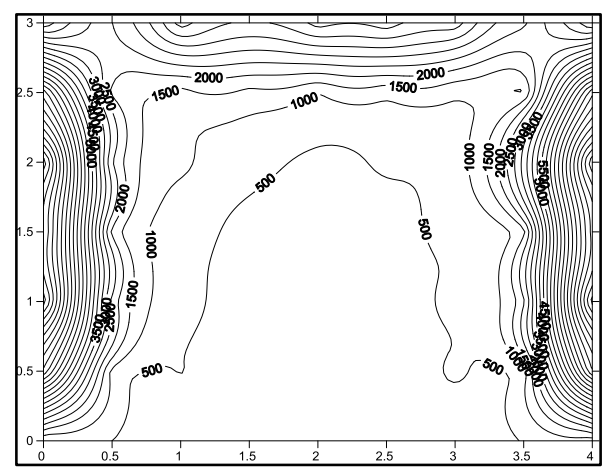

Fig. (12b): Light contouring map at condensed heart $\left(\mathbf{T}_{6}\right)$.

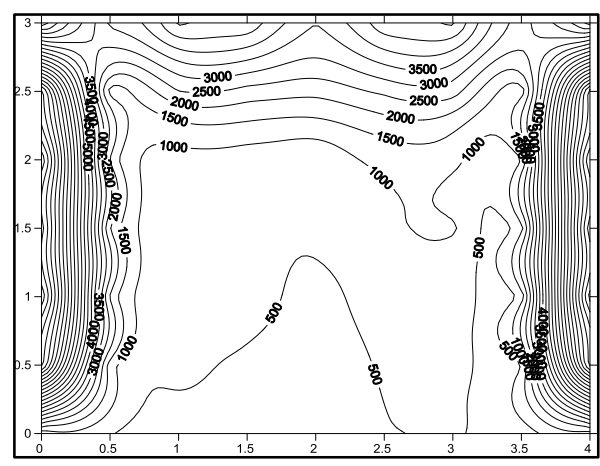

Fig. (12d): Light contouring map amplified production $\left(\mathbf{T}_{4}\right)$.

Fig. (12): Light contouring map of the chamber full section under medium intensity light.

3.3. Production densities under high intensity light: Figs. (14a, b, c and d) and (15a, b, c and d) show contouring maps. Rows No. 9 to 12 in tables (2) and (3) show light intensity variances, and the product criteria. Due to the simulation in exception of the intensity of light $\left(129601 \mathrm{~m} / \mathrm{m}^{2}\right)$, these results take the same trend mentioned above, but in greater values. 
Although the increasing in light intensity is steady, the increasing rates in the product criteria decrease. This decrease could be referred to the lack of Carbon Dioxide in the chamber environment. This result agrees with Carstensen et al. 2017.

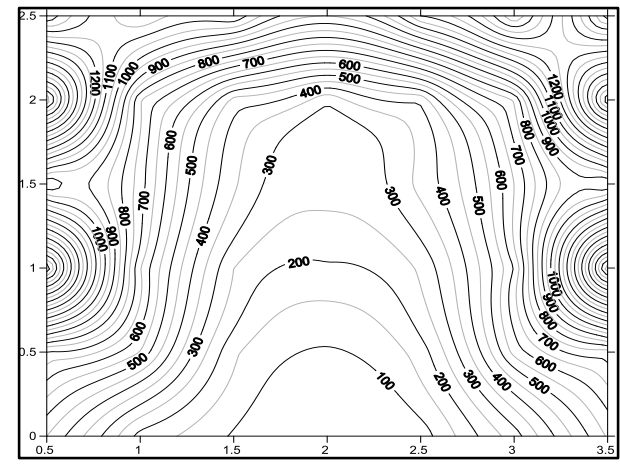

Fig. (13a): Light contouring map for condensed production $\left(T_{5}\right)$.

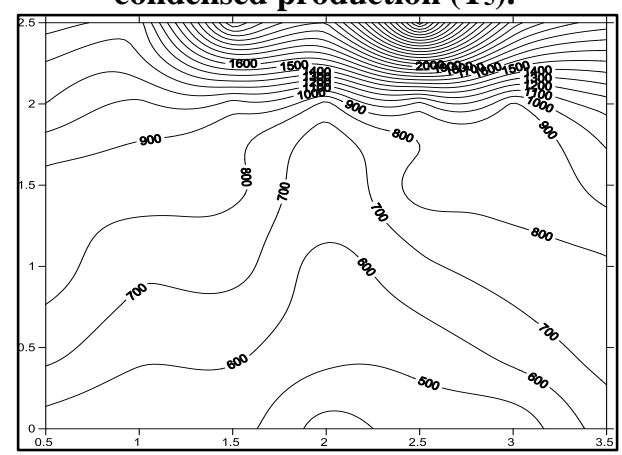

Fig. (13c): Light contouring map for vacated heart $\left(\mathbf{T}_{7}\right)$.

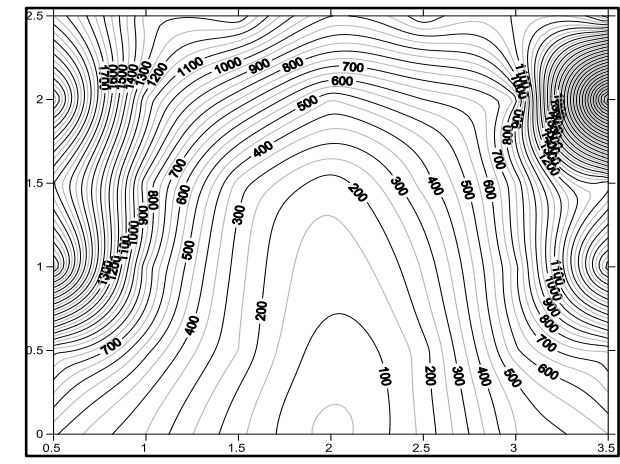

Fig. (13b): Light contouring map for condensed heart $\left(\mathbf{T}_{6}\right)$.

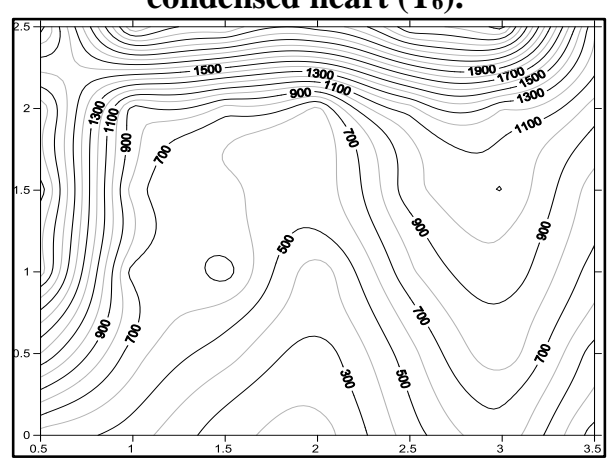

Fig. (13d): Light contouring map for amplified production $\left(\mathbf{T}_{8}\right)$.

Fig. (13): Light contouring map of the chamber heart zone under medium intensity light.

3.4. Light intensity and total production of dry matter: Fig. (16) summarizes the relationship between light intensity and the total production of dry matter for the condensed production, condensed heart, open heart and amplified production. Due to the $\mathrm{Cp}, \mathrm{Cf}$, Ash, EE and NFE is expressed as percentage of the dry matter. The dry matter is considered the main indicator for the quantity and quality of the product. As a result, the best relationships which gives high amounts of dry matter in this figure are found at the condensed production and condensed heart 
under medium intensity of light $\left(86401 \mathrm{~m} / \mathrm{m}^{2}\right)$. Because of the condensed heart consumed two thirds of the consumed grains in condensed production. Therefore, applying the condensed heart under medium intensity light $\left(86401 \mathrm{~m} / \mathrm{m}^{2}\right)$ is ideal production density and light intensity.

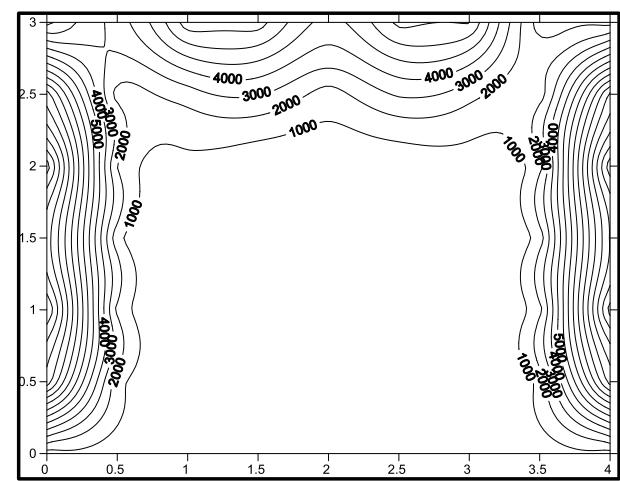

Fig. (14a): Light contouring map at condensed production $\left(T_{9}\right)$.

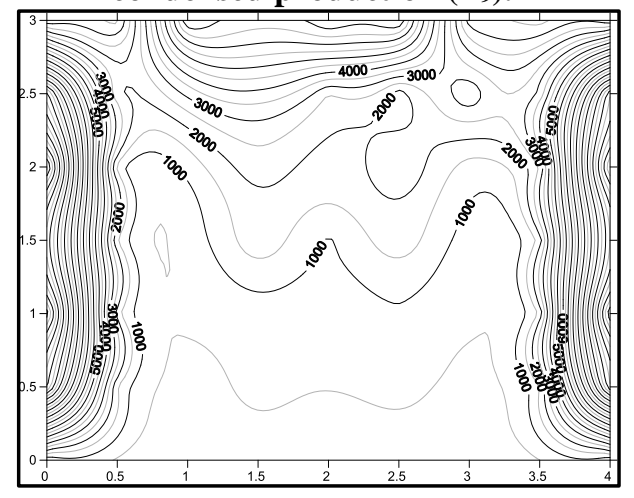

Fig. (14c): Light contouring map at vacated heart under $\left(T_{11}\right)$.

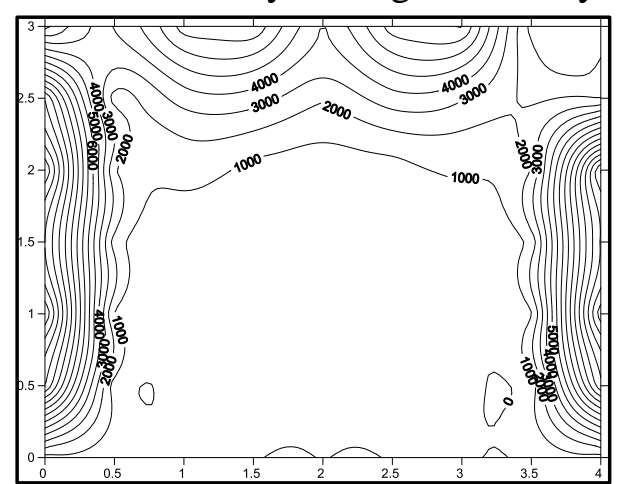

Fig. (14b): Light contouring map at condensed heart $\left(\mathbf{T}_{10}\right)$.

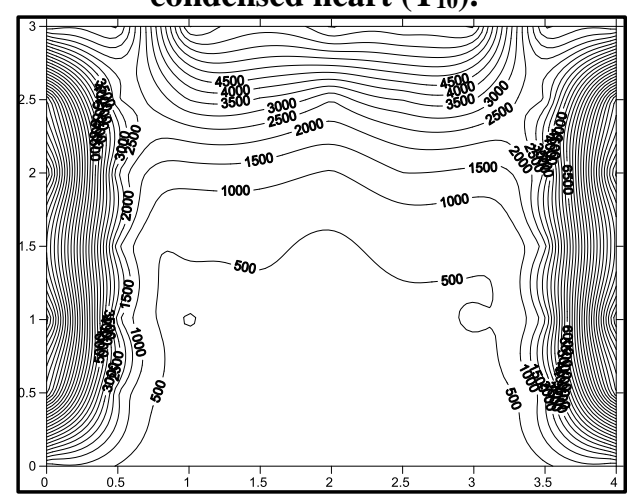

Fig. (14d): Light contouring map at amplified heart $\left(\mathbf{T}_{12}\right)$.

Fig. (14): Light contouring map of the chamber full section under high intensity light.

3.5. Feed intake, milk yield and milk composition: Table (4) shows feed intake, milk yield and milk composition. Rations maintained that sprouting green fodder had higher significant values in both actual and $7 \%$ FCM yields of milk compared to control ration. Feeding Group3 and Group2 significantly increased the content of milk from fat, Solid Not Fat (SNF) and Total Solid (TS) compared to feeding (Group1). Protein and lacttose were significantly higher with ration containing Darawa plus green barley. 


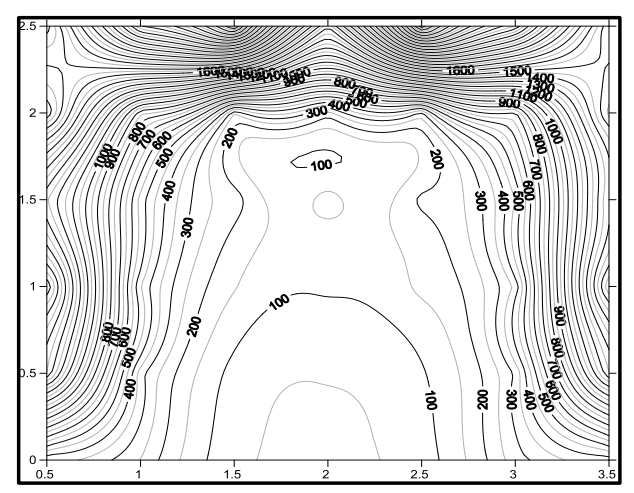

Fig. (15a): Light contouring map at condensed production $\left(\mathbf{T}_{\mathbf{9}}\right)$.

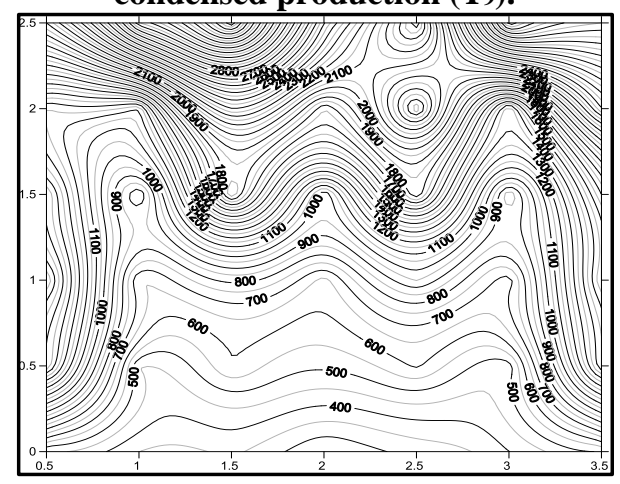

Fig. (15d): Light contouring map at amplified heart $\left(\mathrm{T}_{12}\right)$.

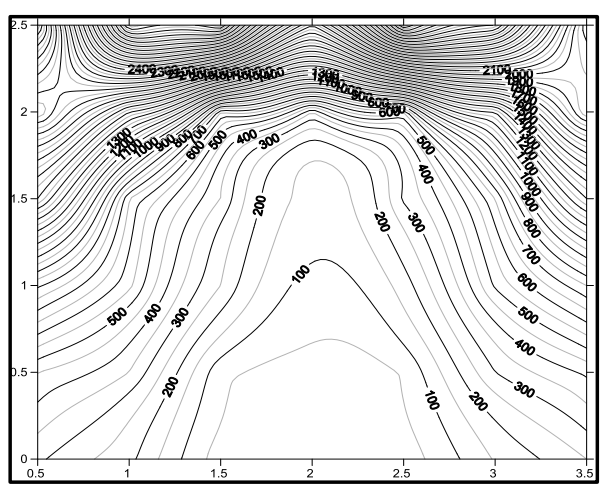

Fig. (15b): Light contouring map at condensed heart $\left(\mathbf{T}_{10}\right)$.

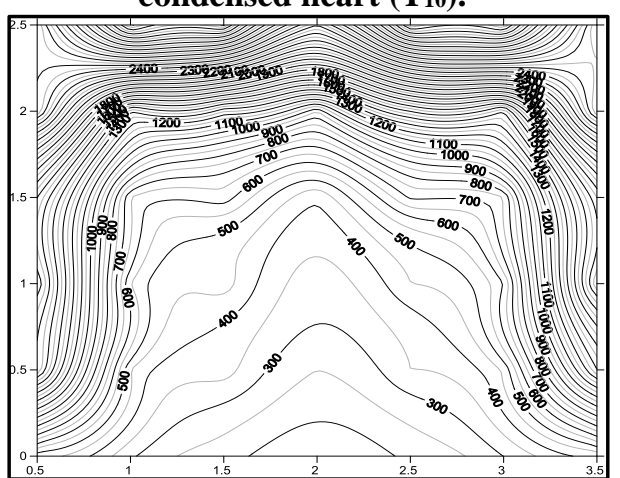

Fig. (15c): Light contouring map at vacated heart under $\left(\mathbf{T}_{11}\right)$.

Fig. (15): Light contouring map of the chamber heart zone under high intensity light.

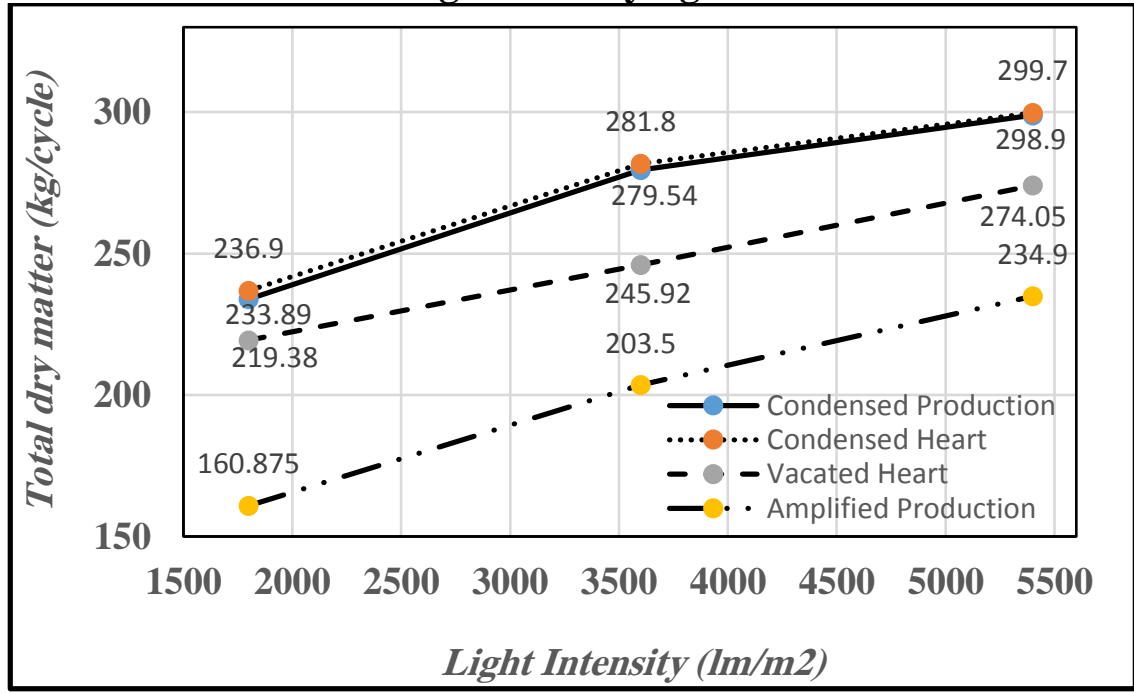

Fig. (16): Relationship between light intensity and total dry matter. 
Therefore, green barley could be used as main source of green forage in lactating buffaloes ration with increasing quantity and quality of milk. These results are higher than those found by Fazaeli et al. 2012, Said and Abo Omar 2015 and Nail et al. 2014.

Table (4): Feed intake, milk yield and milk composition.

\begin{tabular}{|l|c|c|c|c|}
\hline \multicolumn{1}{|c|}{ Item } & \multicolumn{4}{c|}{ Experimental rations } \\
\hline & Group 1 & Group 2 & Group 3 & $\mathbf{\pm S E}$ \\
\hline Feed intake, h/d, kg \\
$\begin{array}{l}\text { Concentrate feed } \\
\text { mixture }\end{array}$ & 7.50 & 7.50 & 7.50 & \\
\hline Wheat straw & 3.00 & 3.00 & 3.00 & \\
\hline Darawa & 18.50 & 9.25 & ----- & \\
\hline Green barley & ------ & 11.56 & 23.12 & \\
\hline Daily milk yield (kg/h/day) & 7.98 & 8.55 & 8.96 & 0.41 \\
\hline Actual yield & $8.05^{\mathrm{b}}$ & $9.75^{\mathrm{a}}$ & $10.34^{\mathrm{a}}$ & 0.45 \\
\hline 7\% fat corrected* & $7.09^{\mathrm{b}}$ & $8.34^{\mathrm{a}}$ & $8.47^{\mathrm{a}}$ & 0.30 \\
\hline Milk composition (\%) & 3.28 & 3.30 & 3.37 & 0.06 \\
\hline Fat & 5.37 & 5.44 & 5.58 & 0.12 \\
\hline Protein & $16.64^{\mathrm{b}}$ & $17.96^{\mathrm{a}}$ & $18.36^{\mathrm{a}}$ & 0.35 \\
\hline Lactose & $9.55^{\mathrm{b}}$ & $9.62^{\mathrm{b}}$ & $9.89^{\mathrm{a}}$ & 0.33 \\
\hline Total solid & 0.90 & 0.88 & 0.94 & 0.63 \\
\hline Solid not fat & \multicolumn{3}{|l}{} \\
\hline Ash &
\end{tabular}

\section{CONLUSION}

Contouring maps and variance analysis reveal that light uniformity improved through the condensed heart, open heart and amplified production systems comparing with the condensed production system. Due to the small capacity (50\%) of the amplified production system, the production capacity is small comparing with the condensed production. Due to the limitation of the distance between the vertical rows in the open heart, the improvement is not satisfied. Also, because of the condensed heart consumed two thirds of the grains give the same production in condensed production. Therefore, applying the condensed heart under medium intensity of light $\left(36001 \mathrm{~m} / \mathrm{m}^{2}\right)$ through $12 /$ h.day (in exception of the first three days) is ideal for production density and light intensity. Also, green barley could be used as main source of green forage in lactating buffaloes ration with increased quantity and quality of milk. 


\section{REFERENCES}

Ahlman L., D. Bånkestad and T. Wika 2017, Using chlorophyll a fluorescence gains to optimize LED light spectrum for short term photosynthesis, Computers and Electronics in Agriculture, Volume 142, Part A:Pp 224-234

Aminia H., LijunWang, A.Hashemisohia, A.Shahbazib, M. Bikdasha, D. KCa and W. Yuanc 2018, An integrated growth kinetics and computational fluid dynamics model for the analysis of algal productivity in open raceway ponds, Computers and Electronics in Agriculture, Volume 145:Pp 363-372

Brazaityte, A., P. Duchovskis and A. Urbonaviciute, 2010, Effect of light emitting diodes on growth of tomatoes transplants, Zemdribyste- Agric. vol. 97, No.2:Pp89-98

Carney, M. J., P. Venetucci and E. Gesick 2016, LED lighting in controlled environment agriculture energy evaluation, Measurement and Validation, Conservation Applied Research \& Development (CARD) FINAL REPORT:Pp1-46, http://mn.gov/commerce-stat/pdfs/card-reportgreenhouse-led.pdf

Carstensen A., T. Pocock, D. Bånkestad, T. Wik 2017, Remote detection of light tolerance in Basil through frequency and transient analysis of light induced fluorescence, Computers and Electronics in Agriculture, Volume 127:Pp 289-301

Delepoulle S., C. Renaud and M. Chelle 2009, Improving Light Position in a Growth Chamber through the Use of a Genetic Algorithm, Arti. Intel. Techn. for Comp. Graph., SCI 159:Pp. 67-82.

Dong C., D. Hu, and M. Wang 2014, Analysis and optimization of the effect of light and nutrient solution on wheat growth and development using an inverse system model strategy, Computers and Electronics in Agriculture, Volume 109:Pp 221-231

Fazaeli H., H.A. Golmohammadi, S.N. Tabatabayee and M. AsghariTabrizi 2012, Productivity and Nutritive Value of Barley Green Fodder Yield in Hydroponic System, World Applied Sciences Journal 16 (4):Pp 531-539

Gonzalez E. O., D. A. Lumbreras and R. Y. Tsonchev 2013, Intelligent lighting system for plant growth and development, Computers and Electronics in Agriculture, Volume 92:Pp 48-53 
Grbic, N., M. Bohme, K. Paschko and I. Pinker 2014 , Effect of different light spectra using LEDs and colored plastic films on growth and internal quality of Vietnamese coriander (POLYGONUM ODORATUM), Proceedings of the international conference "Horticulture in quality and culture of life" Lednice, Czech Republic :Pp 26-33

Hegab K. K. 2017a, Rice straw recycling for developing the hydroponics sprouted barley production and conserving the environment, Misr J. of Agric. Eng. 34 (4-1): Pp 1897 - 1922.

Hegab K. K. 2017b, Successive management programs for the deficit water resources in hydroponics and soilless green fodder production, Misr J. of Agric. Eng. 34 (4-1):Pp 1869 - 1896.

Houser, K. W. , M. Weia and M. P. Royer 2011, Illuminance uniformity of outdoor sports lighting, LEUKOS: The Journal of the Illuminating Engineering Society of North America, Engineering Society of North America 7(4):Pp221-235

Ishii K. and T. Furuichi 2014, Influence of moisture content, particle size and forming temperature on productivity and quality of rice straw pellets, Waste Management, Volume 34, Issue 12:Pp 2621-2626

Kaur D., N. K. Bhardwaj and R. K. Lohchab 2017, Prospects of rice straw as a raw material for paper making, Waste Management, Volume 60 :Pp 127-139

I.arif, K. and H. F. Abbas, 2015, Design and implementation a smart greenhouse, IJCSMC, Vol. 4, Issue. 8:Pp 335 - 347

Landau S. and B. S. Everitt 2004, A Handbook of statistical analyses using SPSS, by Chapman \& Hall/CRC Press LLC, SPSS U.K. Ltd., 1st Floor St. Andrew's House, United Kingdom GU21 6EB:Pp 1-339.

Mahdavian, $M$ and N. Wattanapongsakorn 2017, Optimizing greenhouse lighting for advanced agriculture based on real time electricity market price, Hindawi, Mathematical Problems in Engineering Volume 2017, Article ID 6862038, 11 pages

Miyoshi T., Y. Ibaraki and Y. Sago 2016, Development of an android-tabletbased system for analyzing light intensity distribution on a plant canopy surface, Computers and Electronics in Agriculture, Volume 122:Pp 211217

Muneer, S. , E. J. Kim, J. S. Park and J. H. Lee 2014, Influence of green, red and blue light emitting diodes on multiprotein complex proteins and 
photosynthetic activity under different light intensities in lettuce leaves (Lactuca sativa L.), Int. J. Mol. Sci. Volume 15:Pp 4657-4670

Nail P K, R B Duri, M Karunakaran N, B K Swain and N P Singh, 2014, Effect of feeding hydroponics maize fodder on digestibility of nutrients and milk production in lactating cows, Indian Journal of Animal Sciences 84 (8): Pp880-883

Nelson, J. A. and B. Bugbee (2014), Economic analysis of greenhouse lighting: Light Emitting Diodes vs. High Intensity Discharge Fixtures, PLOS ONE, 9(6): e99010. doi:10.1371/journal.pone.0099010

Oile, M. and A. Virsile 2013, the effect of light-emitting diode lighting on greenhouse plant growth and quality, Agric. and Food Science, Volume 22:Pp223-234.

Riya S., K. Suzuki, L. Meng, S. Zhou, A. Terada and M. Hosomi 2018, The influence of the total solid content on the stability of dry-thermophilic anaerobic digestion of rice straw and pig manure, Waste Management, Available online 2, https://doi.org/10.1016/j.wasman.2018.02.033

Said A. M. A. and J. Abo Omar, 2015, The biological and economic feasibility of feeding barley green fodder to lactating Awassi Ewes, Open Journal of Animal Sciences, Volume 5:Pp99-105

Saidab N., T.Bisharaa, A. G.Maravera and M. Zamorano, 2013, Effect of water washing on the thermal behavior of rice straw, Waste Management, Volume 33, Issue $11:$ Pp2250-2256

Sakhonwasee S., K. Tummachai and N. Nimnoy 2017, Influences of LED Light Quality and Intensity on Stomatal Behavior of Three Petunia Cultivars Grown in a Semi-closed System, Environ. Control Biol., 55 (2):Pp93-103

Sarnklong, C., J. W. Cone, W. Pellcaan, and W. H. Hendriks, 2010, Utilization of rice straw and different treatments to improve its feed value for ruminants: A review, Asian-Aust. J. Ani. Sci. Vol. 23(5):Pp 680-692.

Schulze, P. S. C., J. Varela and J. A. P. Vargas-Machuca 2014, Effects of light quality supplied by light emitting diodes (LEDs) on microalgal production, M. Sc. , Universidade do Algarve Faculdade de Ciências e Tecnologia, file:///C:/Users/Khaled/Downloads/Master\%20Thesis\%20Peter\%20Simo n\%20Claus\%20Schulze.pdf 
Senola R., S. Kilicb and K. Tasdelena 2016, Pulse timing control for LED plant growth unit and effects on carnation, Computers and Electronics in Agriculture, Volume 123:Pp 125-134

Toutenburg H. and Shalabh 2009, Statistical analysis of designed experiments, Third Edition, publisher (Springer Science+Business Media, LLC, 233 Spring Street, New York, NY 10013, USA).

Wishkerman A. and E. Wishkerman 2017, Application note: A novel lowcost open-source LED system for microalgae cultivation, Computers and Electronics in Agriculture, Volume 132:Pp 56-62

Yeab J., D. Lia,Y. Suna, G. Wangb, Z. Yuana, F. Zhena and Y. Wanga 2013, Improved biogas production from rice straw by co-digestion with kitchen waste and pig manure, Waste Management, Volume 33, Issue 12:Pp 2653-2658

Young H. D., R. A. Freedman and A. L Ford 2008, University Physics, $12^{\text {th }}$ Edition, Pearson Edition, Inc., Wesley , 1301 Sansome ST. CA 941111, USA.

Zhou C., Z. Liu, Z. Huang, M. Dong, X. Yu and P. Ning June 2015, A new strategy for co-composting dairy manure with rice straw: Addition of different inocula at three stages of composting, Waste Management, Volume 40:Pp 38-43

Zumtobel L. G. 2017, The lighting Handbook, 5th edition, Schweizer Strasse 30, Postfach 72, 6851 Dornbirn, AUSTRIA. info@zumtobel.info

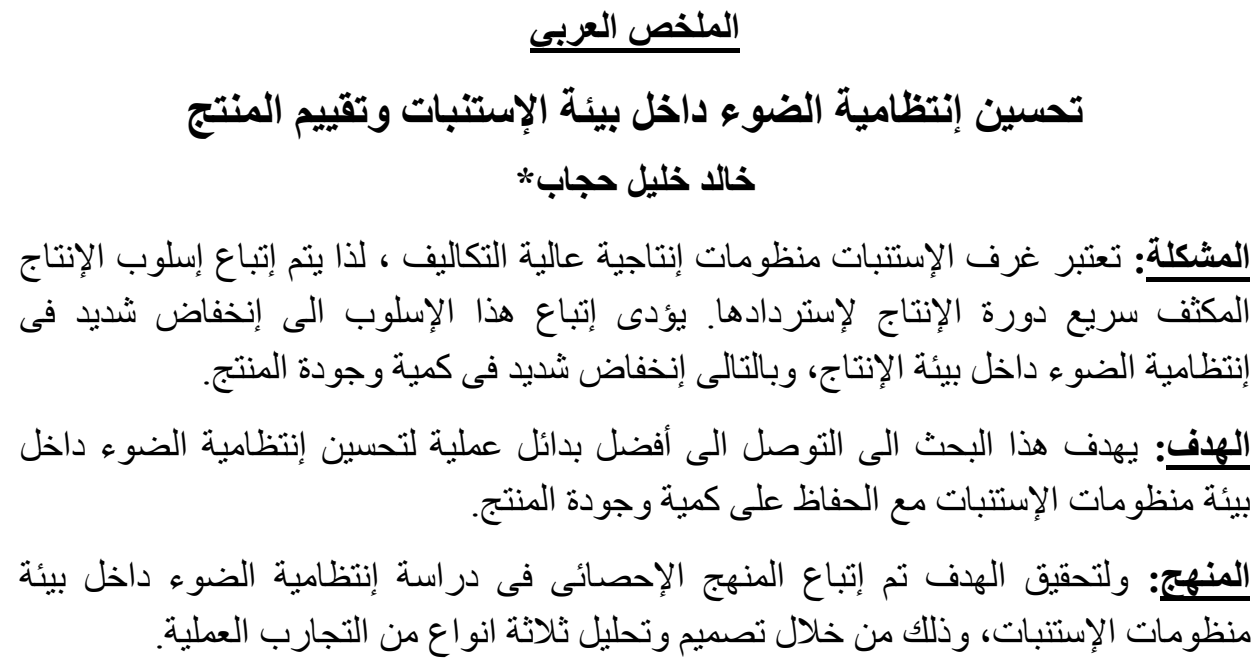

*قمس الهندة الزراعيةـ كلية الزراعةـ جامعة القاهرة 


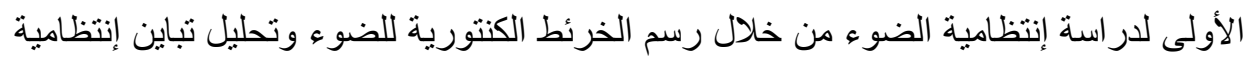

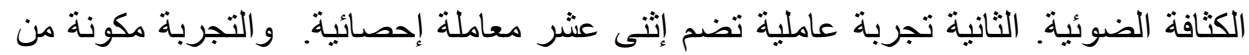

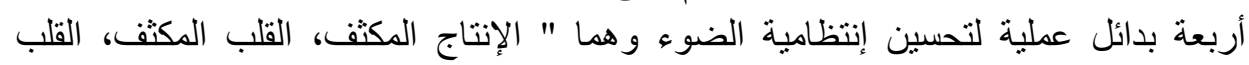

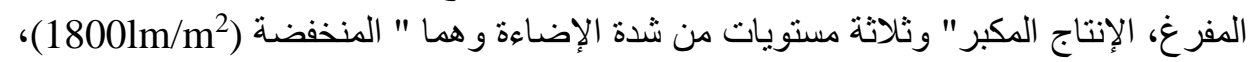

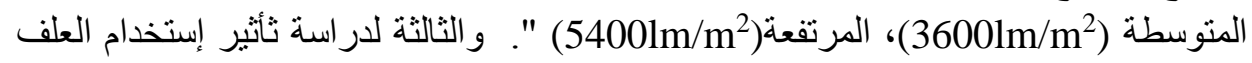

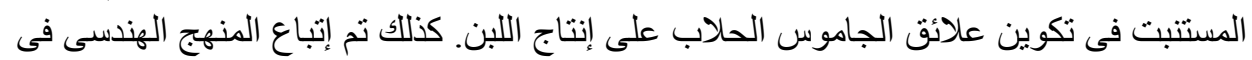

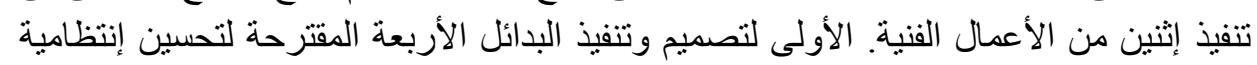

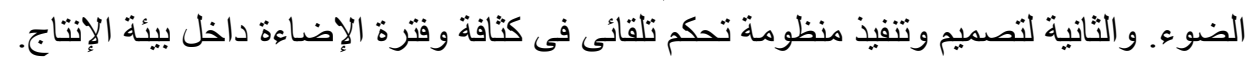

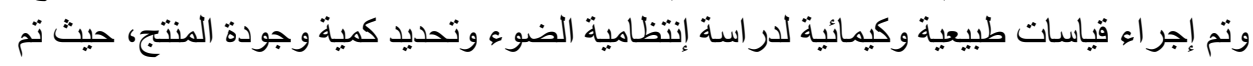

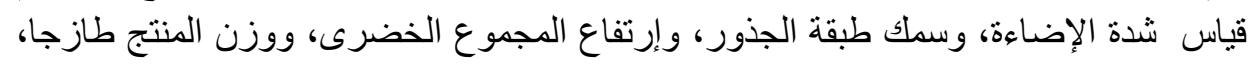

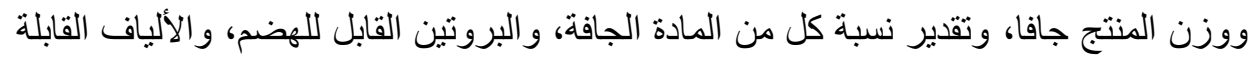

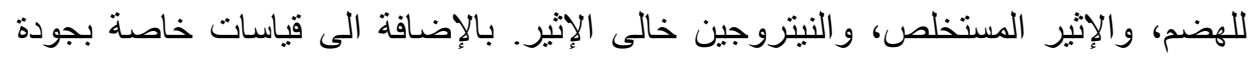
اللبن.

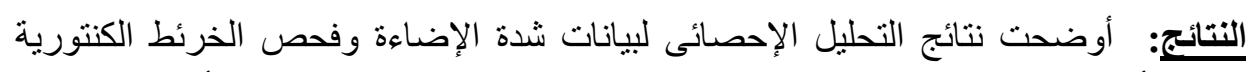

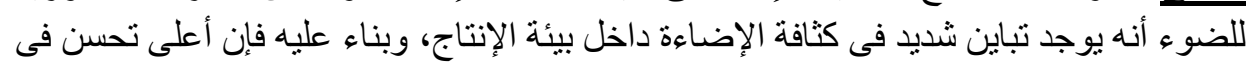

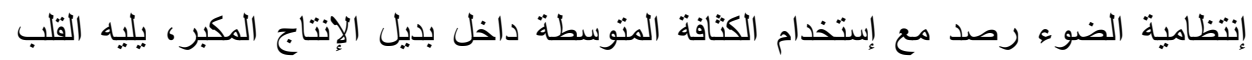

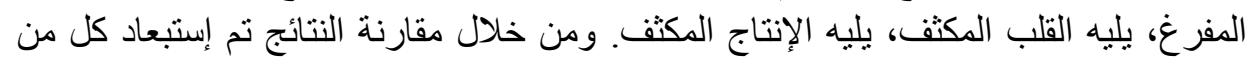

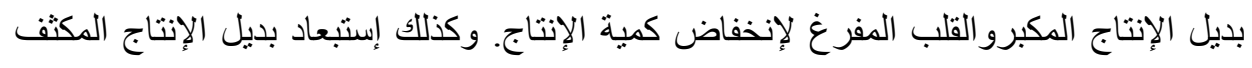

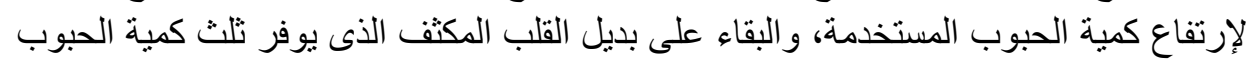

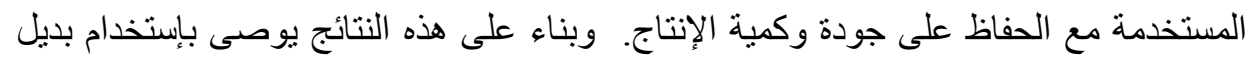

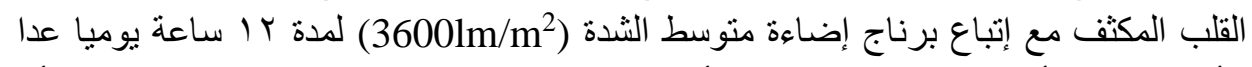

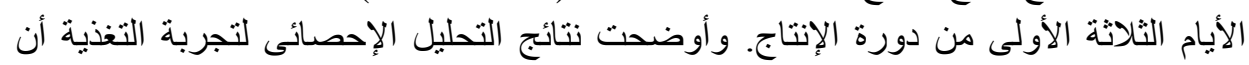

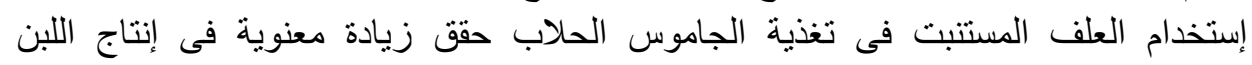

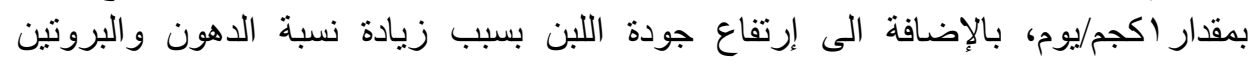
و اللاكتوز و المو اد الصلبة. 